\title{
Cadmium uptake by marine micro-organisms in the English Channel and Celtic Sea
}

\author{
Joanna L. Dixon ${ }^{1, *}$, Peter J. Statham ${ }^{2}$, Claire E. Widdicombe ${ }^{1}$, Rachel M. Jones ${ }^{1}$, \\ Susana Barquero-Molina ${ }^{1}$, Brian Dickie ${ }^{2}$, Malcolm Nimmo ${ }^{3}$, Carol M. Turley ${ }^{1}$
}

\author{
${ }^{1}$ Plymouth Marine Laboratory, Prospect Place, West Hoe, Plymouth PL1 3DH, UK \\ ${ }^{2}$ School of Ocean and Earth Sciences, National Oceanography Centre, European Way, Southampton SO14 3ZH, UK \\ ${ }^{3}$ School of Earth, Ocean and Environmental Sciences, University of Plymouth, Drake Circus, Plymouth PL4 8AA, UK
}

\begin{abstract}
A series of shipboard experiments using the radiotracer ${ }^{109} \mathrm{Cd}$ investigated the role of phytoplankton and bacteria in the uptake of dissolved $\mathrm{Cd}$ in the English Channel and Celtic Sea. The results demonstrate that $\mathrm{Cd}$ uptake is related to rates of primary production and bacterial numbers. Statistical analysis of plankton species abundance infer that Rhizosolenia, Chaetoceros and Pseudonitzschia diatom species are largely responsible for the higher Cd uptake observed in the $>5 \mu \mathrm{m}$ size fraction during a diatom-dominated spring bloom. Total $\mathrm{Cd}$ uptake rates during winter non-bloom conditions were between 0.04 and $0.29 \mathrm{pmol} \mathrm{l}^{-1} \mathrm{~h}^{-1}$, and increased to between 0.43 and $1.23 \mathrm{pmol}^{-1}$ $\mathrm{h}^{-1}$ during diatom bloom conditions. These uptake rates are consistent with the seasonal surface depletion of Cd reported in the Celtic Sea and attributed to uptake by phytoplankton bloom material. A calculated Cd:C ratio of $3.1 \mu \mathrm{mol} \mathrm{mol}{ }^{-1}$ for natural plankton samples of the Celtic Sea agrees well with results of previous culture studies, which have reported ratios between 0.1 and $5.0 \mu \mathrm{mol}$ $\mathrm{mol}^{-1}$ for the coastal diatoms Thalassiosira weissflogii and T. pseudonana. Cd uptake was also linearly related to bacterial numbers, which was attributed to surface adsorption of Cd ions onto bacterial particles which have relatively high specific surface areas. These results demonstrate surface adsorption of $\mathrm{Cd}$ onto bacterial surfaces, and other biogenic non-living particles, i.e. 'passive $\mathrm{Cd}$ uptake', which is significantly augmented during a spring diatom bloom.
\end{abstract}

KEY WORDS: Cadmium uptake - Cadmium carbon ratios · Phytoplankton · Diatom blooms · Heterotrophic bacteria · Celtic Sea

Resale or republication not permitted without written consent of the publisher

\section{INTRODUCTION}

The similarity in open ocean vertical profiles of dissolved trace metals such as cadmium (Cd) and zinc ( $\mathrm{Zn}$ ) and the major nutrients, phosphate and silicon respectively, has been well documented (e.g. Boyle et al. 1976, Hunter \& Boyd 1999, Morel \& Price 2003). Typical depth profiles of many trace metal micronutrients (e.g. $\mathrm{Fe}, \mathrm{Zn}$ ) and nutrient analogs (e.g. Cd, Ni) increase with depth and covary with the concentration of major nutrients. This covariance has suggested that the concentrations of these metals within the oceanic nutricline are largely regulated by uptake and regeneration cycles similar to those of the major nutrients.

Marine microorganisms are largely responsible for the cycling, and therefore the distribution of many macronutrients and trace elements in the sea (Lane \& Morel 2000). All microbes, whether prokaryotic or eukaryotic, employ metal species for structural functions and catalytic enzyme functions (Ehrlich 1997). Bacteria interact with trace metals, both to their benefit to support biochemical requirements $(\mathrm{Ca}, \mathrm{Mg}, \mathrm{Fe}$, $\mathrm{Co}, \mathrm{Ni}, \mathrm{Cu}$ etc.), and to their detriment at elevated concentrations (e.g. toxic Hg, Cd) (Ehrlich 1997). They either bind metal ions at the cell surface or transport them into the cell to support various intracellular functions. Phytoplankton are known to both passively adsorb trace metals onto cell walls and actively assimilate others from seawater by direct incorporation into tissues and inorganic hard parts, and thus must represent important pathways for metal cycling in marine ecosystems (Cullen \& Sherrell 1999). 
Until recently, Cd was generally thought to be universally deleterious to living organisms (Lane \& Morel 2000). Thus its correlation with phosphate in deep ocean profiles coupled with the absence of a known biological function suggested that abiotic processes, e.g. adsorption onto organic particles, controlled the distribution of Cd. However, Cullen et al. (1999) suggested that biological removal of $\mathrm{Cd}$ from ocean waters was related to its utilisation in carbonic anhydrase (CA), and was regulated by dissolved $\mathrm{CO}_{2}$ and $\mathrm{Zn}$ concentrations. Lane \& Morel (2000) showed that under conditions of low ionic $\mathrm{Zn}$ and $\mathrm{pCO}_{2}$ levels typical of the marine environment, the marine diatom Thalassiosira weissflogii showed an increase in growth rate when $\mathrm{Cd}$ was added. This increase was reflected in enhanced levels of cellular CA activity, despite levels of the major, intracellular, Zn-requiring isoform of CA remaining low. Cullen et al. (1999) suggested that there was a specific $\mathrm{Cd}$ CA that was distinct from the Zn CA, whilst Lane \& Morel (2000) isolated a Cd containing protein of $69 \mathrm{kDa}$ from $T$. weissfloggii (Lane et al. 2005) whose levels were modulated by $\mathrm{CO}_{2}$ in a manner consistent with a role for this enzyme in carbon acquisition. These authors concluded that T. weissfloggii expresses a Cd-specific CA under Zn limitation, which replaces the $\mathrm{Zn}$-specific CA in its carbon concentrating mechanism. The replacement of $\mathrm{Zn}$ by $\mathrm{Cd}$ (and Co) observed in CA may also occur in other Zn containing metallo-enzymes, such as alkaline phosphatase, which allows phytoplankton to acquire $P$ from organic compounds (Morel \& Price 2003).

The uptake of metals by bacteria has also been well documented (e.g. Flatau et al. 1988, Yee \& Fein 2001). Low rates of $\mathrm{Cd}$ uptake in certain types of bacteria has been attributed to either chromosomal or a plasmid encoded characteristic resistance (Flatau et al. 1988). Yee \& Fein (2001) suggested that a wide range of bacterial species exhibited nearly identical $\mathrm{Cd}$ adsorption onto bacterial surfaces. More recently, Hu et al. (2002) suggested that $\mathrm{Cd}$ inhibits ammonium oxidation (but not nitrite oxidation) in marine nitrifying bacteria, with the degree of inhibition being a function of the free cation concentration of $\mathrm{Cd}^{2+}$ and not total concentration of the metal.

The majority of the work above relates to the behaviour of $\mathrm{Cd}$ in controlled laboratory systems, and relatively little information exists on the overall interaction of natural microbial populations with $\mathrm{Cd}$ in seawater. Therefore a series of experiments, using the gamma radiotracer ${ }^{109} \mathrm{Cd}$, were designed to investigate the role of phytoplankton and bacteria in the uptake of Cd along a transect running from coastal to offshelf stations in the English Channel and Celtic Sea that included low and high productivity stations.

\section{MATERIALS AND METHODS}

Sampling sites. All reported experiments took place during Cruise D261 of the RRS 'Discovery' between 1 and 14 April 2002. Water samples were collected predawn from 5 stations (Fig. 1; see Table 1) using a Seabird CTD rosette system containing $24 \times 201$ Niskin bottles. Seawater subsamples were taken in acid cleaned, low density polyethylene bottles from 8 depths corresponding to depths equivalent to 97,55 , $33,20,14,7,3$ and $1 \%$ of surface irradiance in the mixed layer. The phytoplankton samples were kept in the dark to avoid light shock, and at in situ temperature. A Lagrangian study of a diatom bloom was undertaken from 6 to 12 April 2002 with an Argos drifter buoy marking the water body. Temperature versus salinity relationships suggested that we were sampling in Lagrangian mode from 8 April onwards (C. Gallienne unpubl. data), after a storm on 7 April which mixed the water column. Experiments for $\mathrm{Cd}$ uptake were carried out at non-bloom stations on 2, 3 and 5 April 2002, and at bloom stations on 8 and 11 April 2002 (Table 1) during the Lagrangian study.

Cadmium uptake. Seawater samples for dissolved Cd analysis were taken with externally closing Niskin bottles fitted with Teflon taps and deployed on Kevlar rope. On retrieval the bottles were taken into the clean container laboratory, and all further handling was carried out observing trace metal cleaning procedures. Total dissolved $\mathrm{Cd}(<0.4 \mu \mathrm{m})$ was determined by graphite furnace atomic absorption spectrometry after pre-concentration and separation from the salt matrix using a chelation-solvent extraction procedure (Bruland et al. 1979), with the mixed dithiocarbamate con-

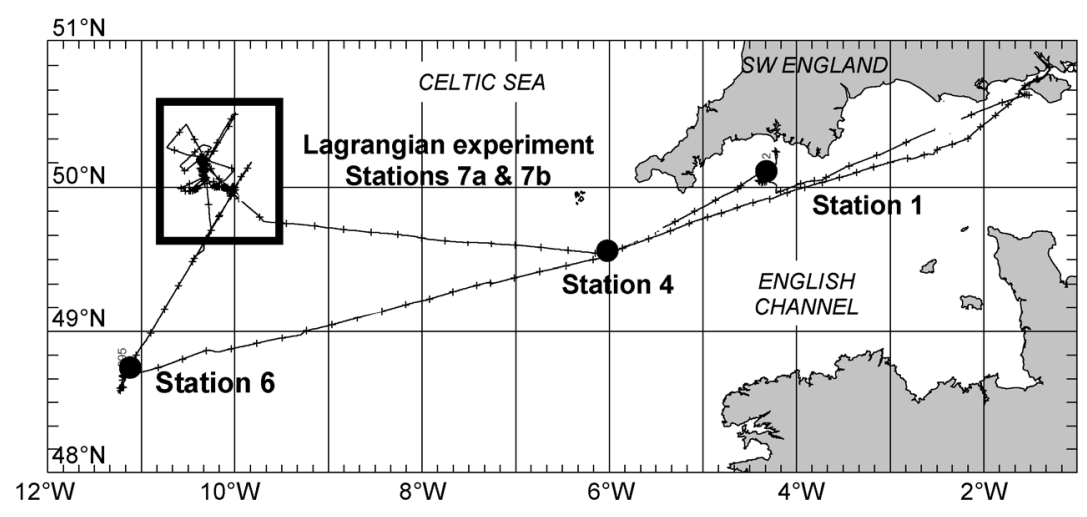

Fig. 1. Location of sampling stations in the English Channel and Celtic Sea between 1 and 14 April 2002 during Cruise D261 of the RRS 'Discovery' 
centrations and $\mathrm{pH}$ modified to allow the extraction of a wider range of elements (Statham 1985). The detection limit for the method was 2.5 pM (3 times the standard deviation of the blank), and the typical precision was $6 \%$ relative standard deviation.

Aliquots of water samples from the 8 depths were transferred into three $250 \mathrm{ml}$ transparent polycarbonate bottles, and into 2 black polycarbonate bottles (for 97 and $1 \%$ surface light penetration depths only). The 2 samples in the black polycarbonate bottles were poisoned by adding an aliquot of $\mathrm{HgCl}_{2}(300 \mu \mathrm{l}$ of $3.5 \%$ w/v solution per $100 \mathrm{ml}$ sample). In the poisoned samples active assimilation processes were stopped, thus providing a measure of passive surface uptake onto particle surfaces (Dixon 1998). However, mercuric ion displacement of Cd ions from surface bound sites could account for a proportion of the apparent decrease in Cd uptake for poisoned samples, and the values used in this study therefore represent lower limits, i.e. maximum uptake rates.

The $\mathrm{pH}$ of each sample was recorded, and each bottle was inoculated with $3.7 \mathrm{kBq}{ }^{109} \mathrm{Cd}$ (corresponding to $8.9 \mathrm{pM}$ of dissolved $\mathrm{Cd}$, half-life $=462 \mathrm{~d}$ ). Because ${ }^{109} \mathrm{Cd}$ is carried in acidic solution $(0.1 \mathrm{M} \mathrm{HCl})$, the $\mathrm{pH}$ of the samples was monitored after spike addition and adjusted to 8.01 (sample pH) with $0.1 \mathrm{M} \mathrm{NaOH}$ (AristaR). Typical total dissolved $\mathrm{Cd}$ concentrations in the English Channel range between 100 and 200 pM (Le Gall et al. 1999). The radiotracer addition therefore represented $<10 \%$ of typical concentrations of stable $\mathrm{Cd}$, whilst ensuring significant counts above background. The bottles were then transferred before dawn to the on-deck incubators, which were fitted with neutral density filters corresponding to approximately $97,55,33,20,14,7,3$ and $1 \%$ of surface irradiance, in order to simulate the light conditions at the appropriate depths (Joint \& Pomroy 1993). Samples were incubated for $24 \mathrm{~h}$ ensuring that the light filters were replaced with dark screens at dusk to minimise interference by ship's lights. Incubations were terminated by filtering each sample sequentially though 5.0 and $0.2 \mu \mathrm{m}$ pore size polycarbonate filters $(47 \mathrm{~mm}$ diameter), which were then dried and stored until return to the laboratory. The ${ }^{109} \mathrm{Cd}$ gamma activity of the filters were counted directly by a Wallac $1480 \mathrm{Na}(\mathrm{Tl})$ gamma detector (at $88 \mathrm{keV}$ ). Counting times were typically $15 \mathrm{~min}$, and counting error was $\leq 5 \%$. Typical 'time zero' controls, whereby samples were spiked with ${ }^{109} \mathrm{Cd}$ and immediately filtered (background activity), were $<1 \%$ of the activity retained on the filters. Corrections were made for this background radioactivity and ${ }^{109} \mathrm{Cd}$ decay. The rate of Cd uptake depends upon the relationship between the incorporation of the tracer ${ }^{109} \mathrm{Cd}$, and the incorporation of stable $\mathrm{Cd}\left([\mathrm{Cd}]_{\mathrm{t}}\right)$, i.e. $[\mathrm{Cd}]_{\mathrm{t}} /\left[{ }^{109} \mathrm{Cd}\right]$ in the dissolved phase. The uptake rates of $\mathrm{Cd}\left(\mathrm{pmol} \mathrm{l}^{-1}\right.$ time $\left.^{-1}\right)$ are therefore calculated from:

$$
\text { Cd uptake }=\frac{\mathrm{dpm}{ }^{109} \mathrm{Cd} \text { on filter } \times[\mathrm{Cd}]_{\mathrm{t}}}{\text { total dpm }{ }^{109} \mathrm{Cd} \text { added } \times \text { time incubation }}
$$

where $\mathrm{dpm}=$ disintegrations $\mathrm{min}^{-1}$ and incubation time was $24 \mathrm{~h}$.

Primary production. The rate of carbon fixation was estimated from the incorporation of ${ }^{14} \mathrm{C}$-bicarbonate as described by Rees et al. (1999). Aliquots of water samples from each depth were transferred into three $60 \mathrm{ml}$ transparent polycarbonate bottles, which had been acid-cleaned to minimise metal contamination, following JGOFS protocols (IOC 1994). Each bottle was inoculated with approximately $370 \mathrm{kBq} \mathrm{NaH}{ }^{14} \mathrm{CO}_{3}$ and transferred to the incubation system and treated as described above for the ${ }^{109} \mathrm{Cd}$ incubations. Incubations were terminated after $24 \mathrm{~h}$ by sequential filtration through 5.0 and $0.2 \mu \mathrm{m}$ pore size filters. These were dried and stored in a desiccator over silica gel. The activity of ${ }^{14} \mathrm{C}$ was measured on board ship using a liquid scintillation counter, the efficiency of which was determined with an external standard, channels ratio method (Joint \& Pomroy 1993, Rees et al. 1999).

Bacterial production. The rate of bacterial carbon production was estimated from the incorporation of ${ }^{3} \mathrm{H}$ leucine into bacterial protein as described by Smith \& Azam (1992). Aliquots of water samples (1.7 ml) from each depth were transferred into six $2 \mathrm{ml}$ microcentrifuge tubes; 2 tubes were prepared with ice-cold trichloroacetic acid (TCA, 5\% final concentration) and served as killed controls. Each tube was inoculated with $20 \mathrm{nM}{ }^{3} \mathrm{H}$-leucine (L- $\left[4,5-{ }^{3} \mathrm{H}\right]$ leucine, TRK636 Amersham Pharmacia Biotech) and incubated at in situ temperature in the dark. Incubations were terminated after $1 \mathrm{~h}$ by the addition of ice cold TCA (5\% final concentration) and stored in the fridge until extraction. For full details of extraction procedures refer to Smith \& Azam (1992). The samples were counted either on board ship or on return to the laboratory in a liquid scintillation counter. Bacterial carbon production was calculated by multiplying incorporation of leucine into bacterial protein by a theoretical carbon conversion factor of $1.55 \mathrm{~kg} \mathrm{C} \mathrm{mol}^{-1}$ leucine (Simon \& Azam 1989, Ducklow et al. 2002, Hoppe et al. 2002).

Bacterial abundance. Duplicate $2 \mathrm{ml}$ samples were fixed with $1 \%$ paraformaldehyde and incubated at $2{ }^{\circ} \mathrm{C}$ for $24 \mathrm{~h}$ subsequent to being stored frozen at $-20^{\circ} \mathrm{C}$. The abundance of heterotrophic bacteria was determined on return to the laboratory with a FACSsort flow cytometer (Becton Dickinson) after staining with SYBR gold nucleic acid stain (Molecular probes, Zubkov et al. 2000).

Plankton identification. Water samples $(250 \mathrm{ml})$ were collected pre-dawn from the $33 \%$ light level and 
fixed in $2 \%$ acid Lugol's solution. Preserved samples were stored in cool, dark conditions until they were analysed in the laboratory by inverted settlement microscopy (Utermöhl 1958). The plankton assemblage (including centric and pennate diatoms, autotrophic dinoflagellates, flagellates, autotrophic ciliates, oligotrichs, other ciliates, tintinnids and heterotrophic dinoflagellates) was characterised as detailed previously in Widdicombe et al. (2002).

Chlorophyll concentration. Chlorophyll concentrations were measured by fluorometric analysis of extracted pigments (Holm-Hansen et al. 1965). Approximately $250 \mathrm{ml}$ water aliquots from each depth were sequentially filtered through 5.0 and $0.2 \mu \mathrm{m}$ pore size polycarbonate filters. Pigments were then extracted from the filters with $90 \%$ acetone (HPLC grade) and stored in the dark at $4^{\circ} \mathrm{C}$ for $12 \mathrm{~h}$ prior to analysis by fluorometry.

Analysis of environmental variables. Multivariate data analysis was performed using the PRIMER (Plymouth Routines In Multivariate Ecological Research) Version 5.0 software package (Clarke \& Warwick 2001) following methods described by Clarke (1993). Environmental data (see Table 2) was analysed using regression analysis and a correlation based principal components analysis (PCA, Clarke \& Warwick 2001). Similarity matrices for environmental data were constructed using square root transformations and the Bray-Curtis similarity measure. Data was transformed to reduce contributions to similarity by abundant species using standard methods described in Clarke \& Warwick (2001), and plankton abundance data was analysed by non-metric multidimensional scaling (MDS, Clarke \& Warwick 2001). A similarity matrix for environmental data (derived from various subsets of the environmental variables with square root transformation) and a similarity matrix for plankton species abundance (square-root transformation) were tested using a routine called RELATE, which is a simple permutation significance test used to calculate the matching coefficient $\rho$. This evaluates how well the plankton species abundance distribution observed between the stations matches the whole environmental database, i.e. Cd uptake, bacterial and primary production, etc. The plankton species contributing to dissimilarities between non-bloom and bloom stations were also investigated using the similarities percentages procedure (SIMPER, Clarke 1993).

\section{RESULTS AND DISCUSSION}

\section{Cd uptake, nutrients, phytoplankton and bacteria}

Non-bloom stations (Stns 1, 4 and 6)

The concentration of total dissolved Cd in surface waters ranged from 100 to $180 \mathrm{pM}$ (Table 1). The lowest concentration occurred at the nearshore Stn 1 (100 pM); although counterintuitive, this agrees with previously published data for this area (Kremling 1985, Cotté-Krief et al. 2002). The concentrations of nitrate and silicate were also lower at Stn 1 than at the other

Table 1. Sampling station characteristics; (M) and (S) denote fully mixed and shallow stratified water column, respectively. Depth: water column depth (euphotic depth); $\left[\mathrm{Cd}_{\mathrm{t}}\right]$ : total dissolved $\mathrm{Cd}$ in euphotic zone (concentration below euphotic zone between 100 and $150 \mathrm{~m}$ ). Primary production (PP) and chlorophyll a (Chl a) concentrations integrated to depth at which irradiance is $1 \%$ of that just below sea surface, with values in parentheses showing percentage of carbon fixed by 0.2 to 5.0 and $>5.0 \mu \mathrm{m}$ size fractions, respectively. Bloom status assigned based on rates of primary production, concentration of chlorophyll and diatom biomass in comparison to literature values. ns: no sample

\begin{tabular}{|c|c|c|c|c|c|c|c|}
\hline $\begin{array}{l}\text { Station } \\
\text { description }\end{array}$ & $\begin{array}{l}\text { Sampling date } \\
\text { (2002) }\end{array}$ & $\begin{array}{l}\text { Depth } \\
\text { (m) }\end{array}$ & $\begin{array}{c}{[\mathrm{CDt}]} \\
(\mathrm{pM})\end{array}$ & $\begin{array}{c}\mathrm{PP} \\
\left(\mathrm{mg} \mathrm{C} \mathrm{m}^{-2} \mathrm{~d}^{-1}\right)\end{array}$ & $\begin{array}{c}\mathrm{Chl} \mathrm{a} \\
\left(\mathrm{mg} \mathrm{m}^{-2}\right)\end{array}$ & $\begin{array}{l}\text { Diatom } \\
\text { biomass } \\
\left(\mathrm{mg} \mathrm{C} \mathrm{m}^{-3}\right)\end{array}$ & $\begin{array}{l}\text { Bloom } \\
\text { status }\end{array}$ \\
\hline $\begin{array}{l}\text { Stn } 1(\mathrm{M}) \\
\text { Nearshore/coastal } \\
\text { English Channel }\end{array}$ & $2 \mathrm{Apr}$ & $\begin{array}{c}74 \\
(30)\end{array}$ & 100 & $\begin{array}{c}281 \\
(56: 45)\end{array}$ & $\begin{array}{c}21.4 \\
(69: 31)\end{array}$ & 0.17 & $\begin{array}{c}\text { Non } \\
\text { bloom }\end{array}$ \\
\hline $\begin{array}{l}\text { Stn } 4(\mathrm{M}) \\
\text { Coastal } \\
\text { English Channel }\end{array}$ & $3 \mathrm{Apr}$ & $\begin{array}{l}106 \\
(30)\end{array}$ & ns & $\begin{array}{c}148 \\
(50: 50)\end{array}$ & $\begin{array}{c}9.1 \\
(67: 33)\end{array}$ & 0.15 & $\begin{array}{c}\text { Non } \\
\text { bloom }\end{array}$ \\
\hline $\begin{array}{l}\text { Stn } 6 \text { (S) } \\
\text { Offshelf } \\
\text { Western Approaches }\end{array}$ & $5 \mathrm{Apr}$ & $\begin{array}{c}2383 \\
(55)\end{array}$ & $\begin{array}{c}180 \\
(170)\end{array}$ & $\begin{array}{c}255 \\
(73: 27)\end{array}$ & $\begin{array}{c}15.8 \\
(73: 27)\end{array}$ & 0.58 & $\begin{array}{c}\text { Non } \\
\text { bloom }\end{array}$ \\
\hline $\begin{array}{l}\text { Stn } 7 \text { a }(\mathrm{S}) \\
\text { On-slope, Great Sole bank } \\
\text { Lagrangian experiment }\end{array}$ & $8 \mathrm{Apr}$ & $\begin{array}{l}133 \\
(40)\end{array}$ & $\begin{array}{c}140 \\
(170)\end{array}$ & $\begin{array}{c}3067 \\
(10: 90)\end{array}$ & $\begin{array}{c}82.3 \\
(8: 92)\end{array}$ & 88 & $\begin{array}{c}\text { Diatom } \\
\text { bloom }\end{array}$ \\
\hline $\begin{array}{l}\text { Stn } 7 b(\mathrm{~b}) \\
\text { On-slope, Great Sole bank } \\
\text { Lagrangian experiment }\end{array}$ & $11 \mathrm{Apr}$ & $\begin{array}{l}130 \\
(35)\end{array}$ & $\begin{array}{c}140 \\
(170)\end{array}$ & $\begin{array}{l}3037 \\
(8: 92)\end{array}$ & $\begin{array}{c}32.5 \\
(5: 95)\end{array}$ & 109 & $\begin{array}{c}\text { Diatom } \\
\text { bloom }\end{array}$ \\
\hline
\end{tabular}


non-bloom stations, 4 and 6 (Fig. 2). Indeed the L4 database (L4 is a local time series station established in 1988 and located at $50^{\circ} 15^{\prime} \mathrm{N}, 04^{\circ} 13^{\prime} \mathrm{W}$, approximately 13 nautical miles due north of Stn 1) shows relatively high phytoplankton biomass ranging between 8 and $20 \mathrm{mg} \mathrm{C} \mathrm{m}^{-3}$ for February and March 2002 (mainly flagellates), which could explain the relatively lower nutrient and dissolved Cd concentrations at Stn 1 compared to Stns 4 and 6 . We assumed that surface $\mathrm{Cd}$ concentrations at Stn 4 , the comparative coastal station, were the same as for Stn 1 . This assumption is supported by data from Cotté-Krief et al. (2002), who reported values between 90 and $116 \mathrm{pM}$ in a similar region of the Celtic Sea shelf during June 1995. Surface $\mathrm{Cd}$ concentrations of $180 \mathrm{pM}$ found offshelf at Stn 6 (in the Western Approaches) were higher than more typical summer depletion values of $65 \pm 43 \mathrm{pM}$ (Cotté-Krief et al. 2002), and showed little difference between surface $(30 \mathrm{~m})$ and deep $(150 \mathrm{~m})$ waters, suggesting winter mixed pre-bloom conditions. This is also reflected in constant and relatively high nitrate and silicate concentrations $(6.9 \pm 0.13$ and $3.6 \pm$ $0.10 \mu \mathrm{M}$ respectively, Fig. 2) in the euphotic zone. Total
Cd uptake rates for non-bloom stations ranged between 0.04 and $0.29 \mathrm{pmol}^{-1} \mathrm{~h}^{-1}$ and were greater in the 0.2 to $5 \mu \mathrm{m}$ size fraction (Fig. 3).

Primary production ranged between 0.7 and $10.5 \mathrm{mg}$ $\mathrm{C} \mathrm{m}^{-3} \mathrm{~d}^{-1}$ (mean of $4.7 \pm 2.4 \mathrm{mg} \mathrm{C} \mathrm{m}^{-3} \mathrm{~d}^{-1}$ ) and 0.2 to $7.7 \mathrm{mg} \mathrm{C} \mathrm{m}^{-3} \mathrm{~d}^{-1}$ (mean of $3.3 \pm 2.1 \mathrm{mg} \mathrm{C} \mathrm{m}^{-3} \mathrm{~d}^{-1}$ ) in the 0.2 to 5.0 and $>5 \mu \mathrm{m}$ size fractions, respectively (Fig. 4 ), and was also generally greater in the smaller size fraction. The percentage of total carbon fixed by the 0.2 to $5.0 \mu \mathrm{m}$ size fraction ranged between 50 and $73 \%$. Seasonal phytoplankton production measurements in the Celtic Sea were reported by Joint et al. (1986), whose Stn CS4 is geographically very close to Stn 6 . Winter production measurements at Stn CS4 ranged between 2 and $4 \mathrm{mg} \mathrm{C} \mathrm{m}^{-3} \mathrm{~d}^{-1}$ for 1 to $5 \mu \mathrm{m}$ cells and $<2 \mathrm{mg} \mathrm{C}$ $\mathrm{m}^{-3} \mathrm{~d}^{-1}$ for cells $>5 \mu \mathrm{m}$. These values agree with the rates determined at Stn 6 during early April 2002 of this study (Fig. 4), and support the suggestion of winter mixed pre-bloom conditions, previously inferred from dissolved Cd measurements. Primary production rates determined at Stns 1 and 4 were relatively low compared to the late May values reported by Joint et al. (1986), also suggesting pre-bloom conditions.
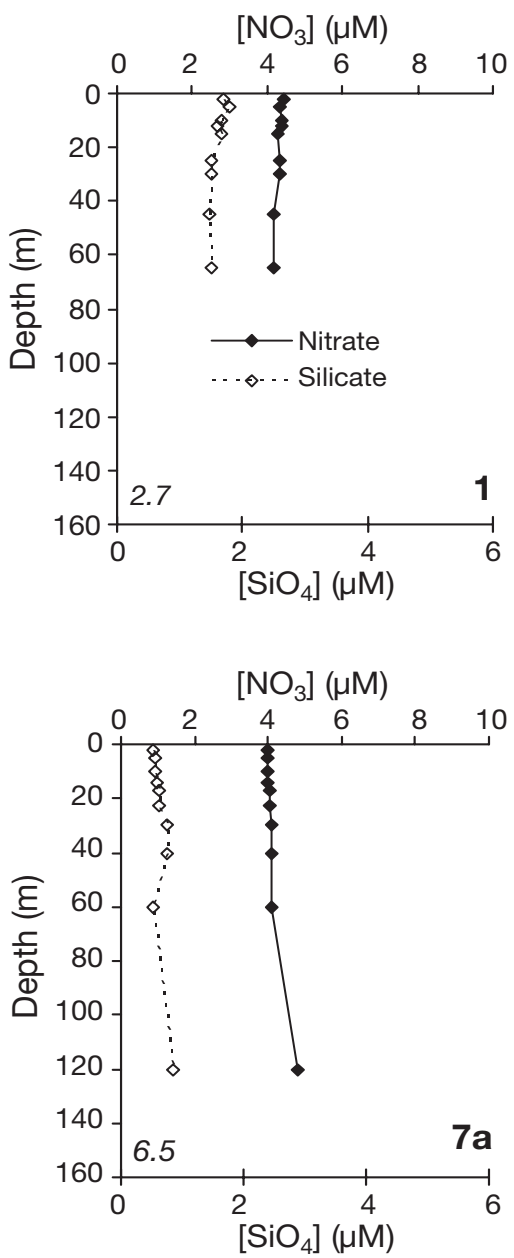
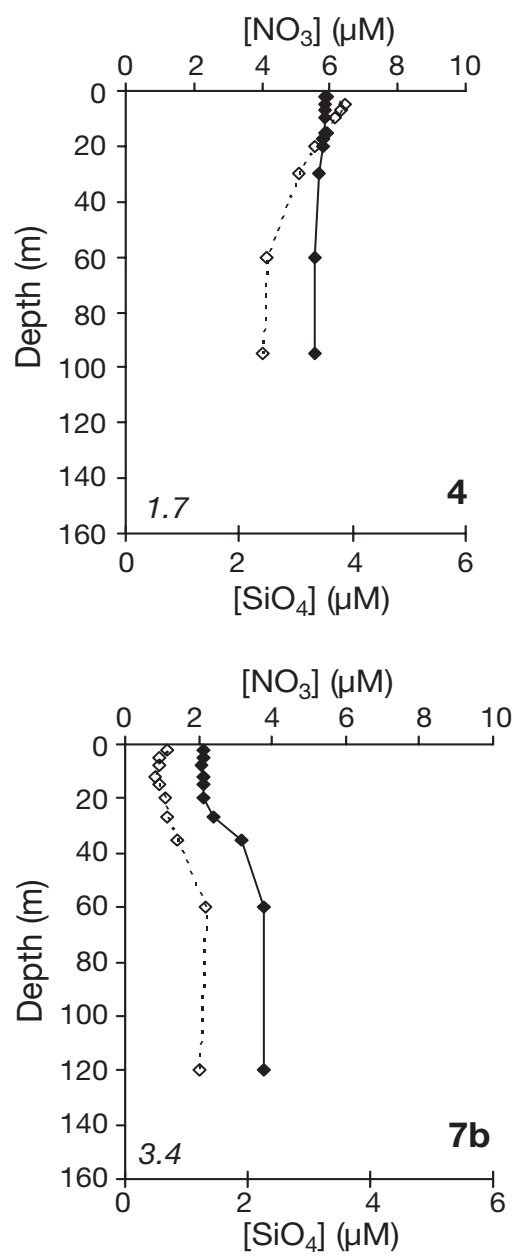

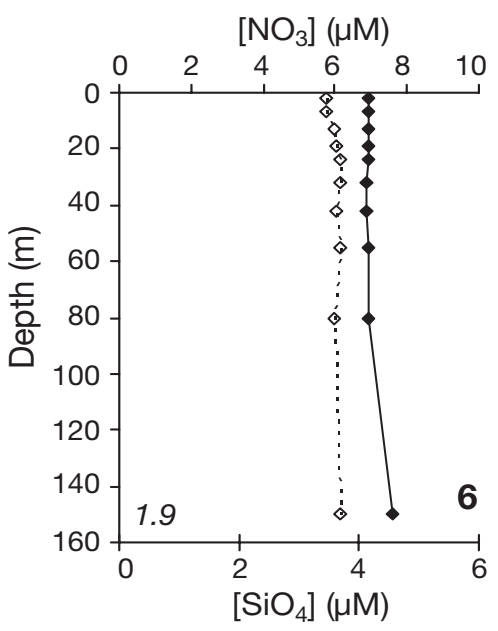

Fig. 2. Depth profiles of nitrate and silicate concentrations $(\mu \mathrm{M})$ at Stns $1,4,6$, $7 \mathrm{a}$ and $7 \mathrm{~b}$. Italicised value in lower lefthand corner of each graph is nitrate to silicate molar ratio 

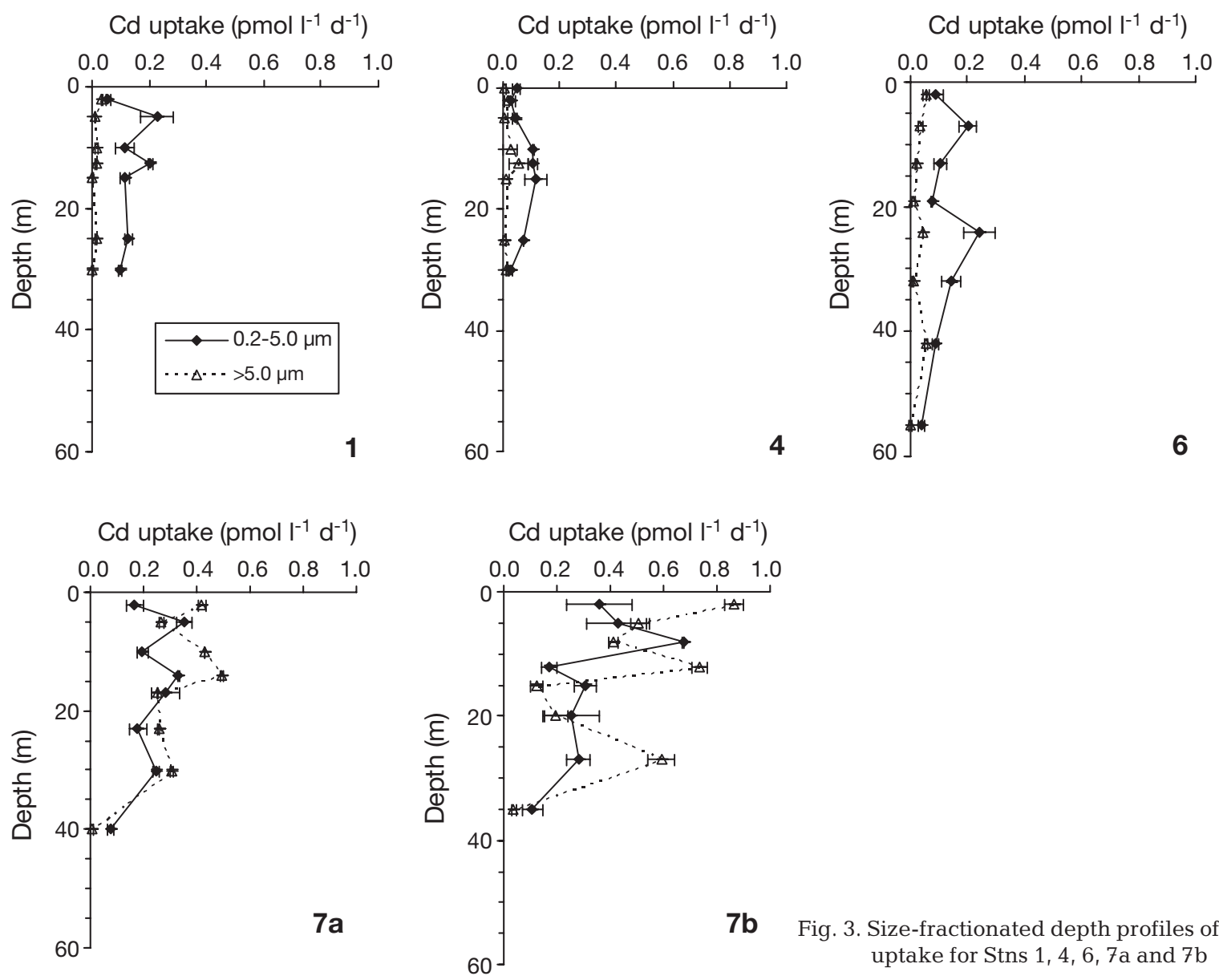

Fig. 3. Size-fractionated depth profiles of ${ }^{109} \mathrm{Cd}$ uptake for Stns 1, 4, 6, 7a and 7b

Concentrations of chlorophyll a ranged from 0.16 to 0.60 and 0.06 to $0.28 \mathrm{mg} \mathrm{C} \mathrm{m}^{-3}$ in the small and large size fractions, respectively, and was always greater in the smaller size fraction (Fig. 4). However, there was very little change in chlorophyll concentrations with depth relative to primary production rates, which generally decreased with increasing depth (Fig. 4).

Bacterial production ranged between 0.01 and $0.57 \mathrm{mg} \mathrm{C} \mathrm{m}^{-3} \mathrm{~d}^{-1}$ (mean of $2.3 \pm 2.3 \mathrm{mg} \mathrm{C} \mathrm{m}^{-3} \mathrm{~d}^{-1}$ ) (Fig. 5) and accounted for between 0.4 and $12 \%$ of carbon fixed by phytoplankton, in agreement with literature ratios that generally report bacterial production:primary production (BP:PP) ratios of 1 to $10 \%$ north of $30^{\circ} \mathrm{N}$ in the North Atlantic (Zubkov et al. 2001, Ducklow et al. 2002, Hoppe et al. 2002). Bacterial numbers ranged between 3.2 and $5.6 \times 10^{8}$ cells $^{-1}$ (Fig. 5), in close agreement with Celtic Sea data reported by Joint \& Pomroy (1987), who found little seasonal variation in bacterial numbers in the euphotic zone, although lowest numbers were prevalent during December and January and late May and June. Like chlorophyll $a$, bacteria numbers showed little variation with depth in the euphotic zone.
The total biomass of plankton at Stns 1, 4 and 6 was low (8.7, 0.98 and $1.90 \mathrm{mg} \mathrm{C} \mathrm{m}^{-3}$, respectively, Fig. 6), and was dominated by autotrophic ciliates $(94,81$ and $54 \%$ respectively), although the biomass of bacteria was higher at Stns 4 and 6 than the plankton biomass (bacterial biomass expressed as a percentage of total biomass of plankton and bacteria for Stns 1, 4 and 6 is 35,79 and $73 \%$, respectively).

Diatom-dominated bloom stations (Stns 7a and 7b)

Surface dissolved Cd concentration at Stns $7 \mathrm{a}$ and $7 \mathrm{~b}$ were $140 \mathrm{pM}$, with below thermocline concentrations of $170 \mathrm{pM}$ (Table 1), consistent with the deep value at Stn 6 . These values are higher than literature values, where concentrations between 30 and $81 \mathrm{pM}$ in the surface $40 \mathrm{~m}$ and between 142 and $145 \mathrm{pM}$ at 100 to $182 \mathrm{~m}$ have been reported for June 1995 (Cotté-Krief et al. 2002). However NE Atlantic central waters (300 to $700 \mathrm{~m}$ ) of the Celtic area average $166 \pm 23$ pM (CottéKrief et al. 2002), so it is likely that the intense storm $\sim 24 \mathrm{~h}$ before the initial sampling for $\mathrm{Cd}$ uptake at this 

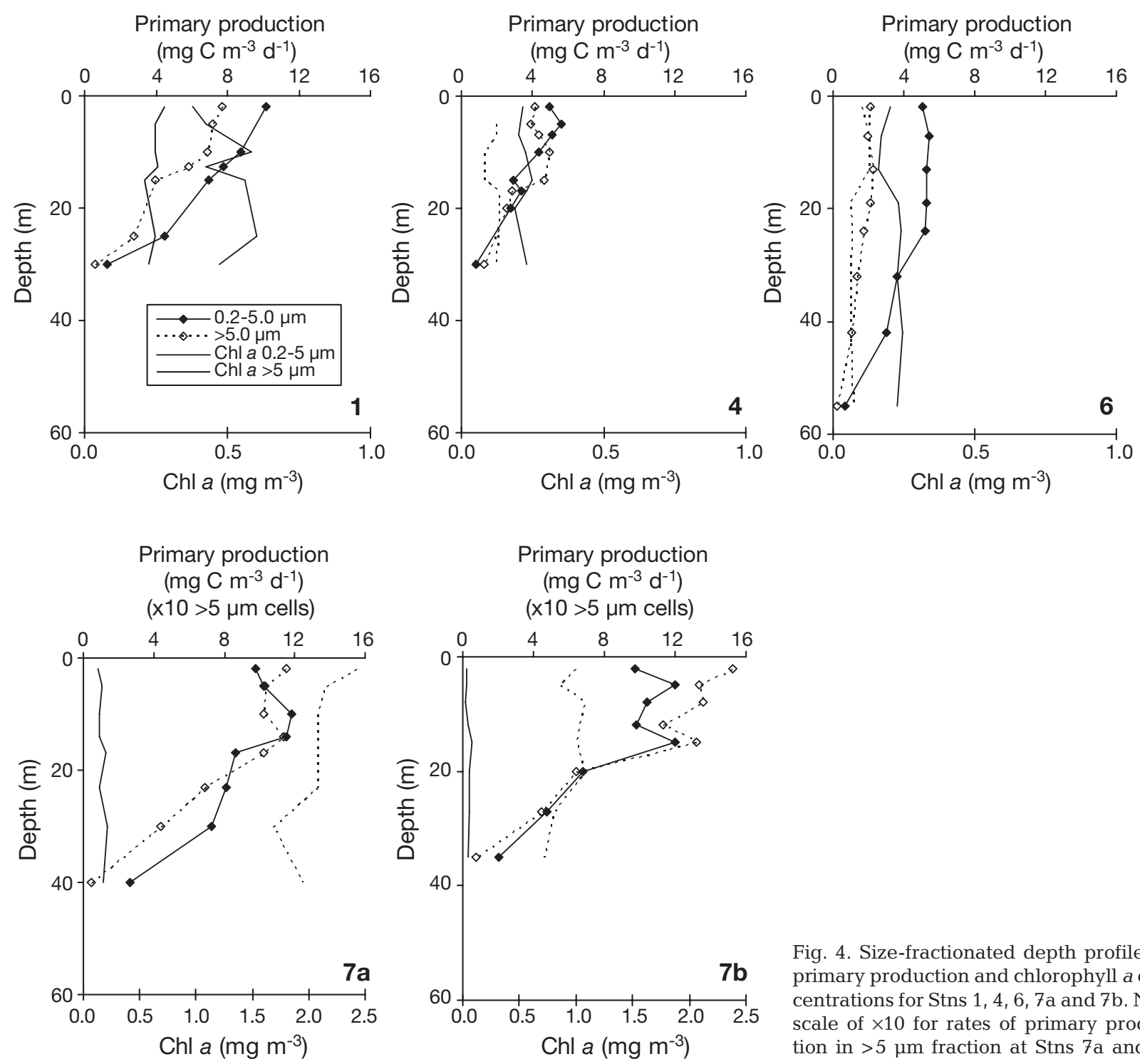

Fig. 4. Size-fractionated depth profiles of primary production and chlorophyll a concentrations for Stns 1, 4, 6, 7a and 7b. Note scale of $\times 10$ for rates of primary production in $>5 \mu \mathrm{m}$ fraction at Stns $7 \mathrm{a}$ and $7 \mathrm{~b}$

station entrained deeper waters, elevating shallower dissolved Cd concentrations. If deep mixing occurred, then the difference between surface and deep Cd concentration data suggests that $\sim 30$ pM surface depletion of dissolved $\mathrm{Cd}$ took place over a period of a couple of days. Total calculated Cd uptake rates at Stns $7 \mathrm{a}$ and $7 \mathrm{~b}$ in the top $30 \mathrm{~m}$ were on average 4.9 times higher than at non-bloom stations, and ranged between 0.43 and $1.23 \mathrm{pmol}^{-1} \mathrm{~h}^{-1}$ (Fig. 3). At these uptake rates, surface Cd depletion of approximately $30 \mathrm{pM}$ would occur in 1 to $3 \mathrm{~d}$. In contrast to non-bloom stations, Cd uptake at Stns $7 \mathrm{a}$ and $7 \mathrm{~b}$ was very similar in both size fractions (Fig. 3). The concentrations of nitrate and silicate were lower than at non-bloom stations, and the nitrate: silicate ratio increased from 1.7 to 2.7 (non-bloom stations) to 6.5 (Fig. 2, Stn 7a), illustrating enhanced silicate depletion relative to nitrate that is characteristic of a diatom bloom.
Primary production ranged from 2.1 to $12.2 \mathrm{mg} \mathrm{C} \mathrm{m}^{-3}$ $\mathrm{d}^{-1}$ (mean of $8.6 \pm 3.2 \mathrm{mg} \mathrm{C} \mathrm{m} \mathrm{m}^{-3} \mathrm{~d}^{-1}$ ) and 4.6 to $153 \mathrm{mg}$ $\mathrm{C} \mathrm{m}^{-3} \mathrm{~d}^{-1}$ (mean of $90 \pm 46 \mathrm{mg} \mathrm{C} \mathrm{m}^{-3} \mathrm{~d}^{-1}$ ) in the small and large size fractions respectively and, in contrast to the non-bloom stations, was consistently greater in the larger size fraction (89.7 and $91.6 \%$ of carbon fixation associated with the $>5.0 \mu \mathrm{m}$ fraction for Stns $7 \mathrm{a}$ and $7 \mathrm{~b}$ respectively). Total integrated rates of primary production were approximately 13 times greater at bloom stations that at non-bloom stations (Table 1). The rates of primary production measured at Stn 7 during this study are approximately $30 \%$ higher than those measured here before (Joint et al. 1986, 2001, Rees et al. 1999, Donald et al. 2001, Pemberton et al. 2004), but are not thought to be unrepresentative of the Celtic Sea shelf ecosystem, and are supported by other in vitro and in situ determinations of plankton production (C. Robinson et al. unpubl.). 

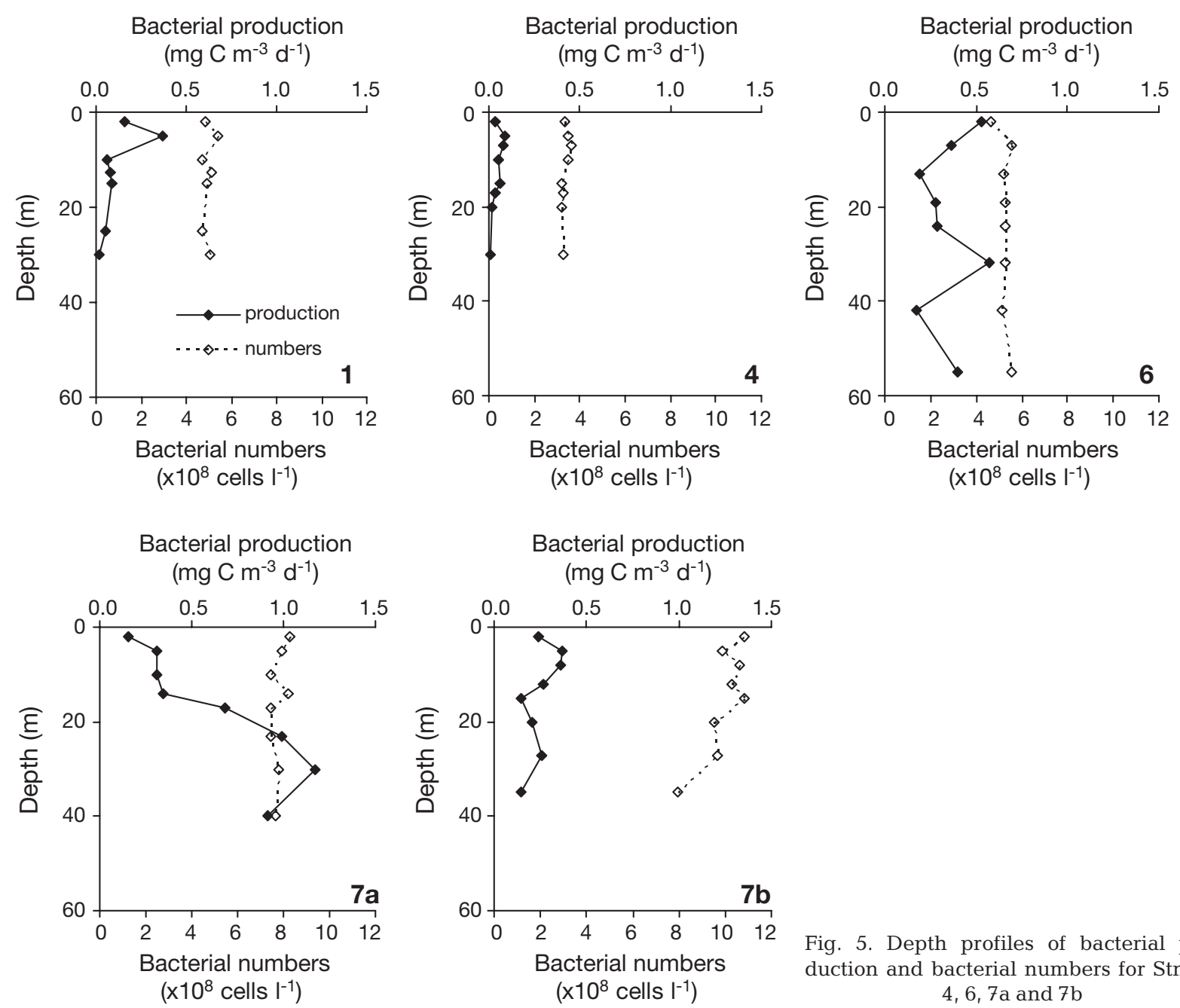

Fig. 5. Depth profiles of bacterial production and bacterial numbers for Stns 1, $4,6,7 \mathrm{a}$ and $7 \mathrm{~b}$

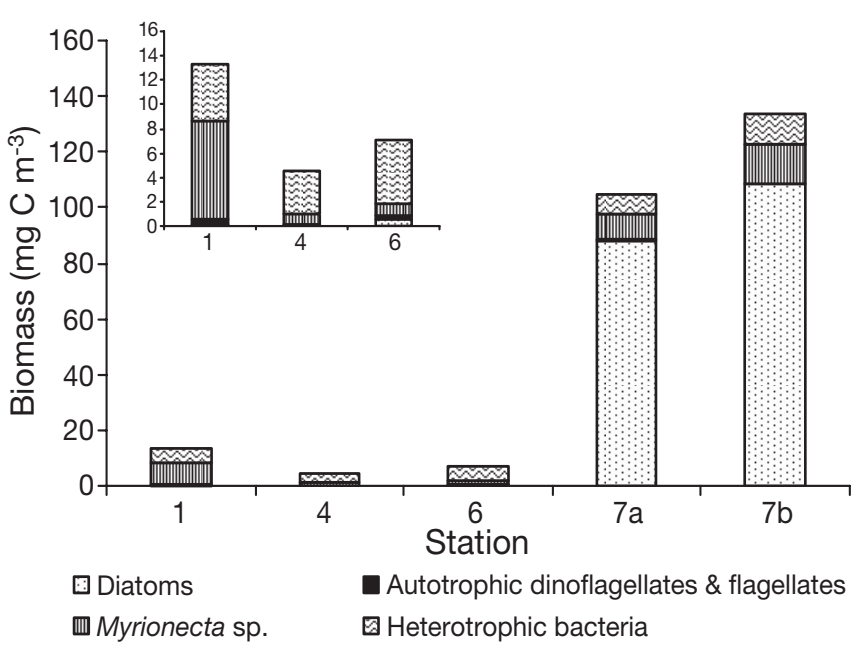

Fig. 6. Plankton species and bacterial biomass at depth of $33 \%$ surface irradiance at each station; inset shows enlargement for Stns 1, 4 and 6
Concentrations of chlorophyll a ranged from 0.02 to 0.21 and 0.72 to $2.4 \mathrm{mg} \mathrm{C} \mathrm{m}^{-3}$ in the small and large size fractions respectively (Fig. 4), and, in contrast to non-bloom stations, were always substantially greater in the $>5 \mu \mathrm{m}$ size fraction. The proportion of chlorophyll $a$ in the $>5 \mu \mathrm{m}$ fraction was between 92 and $95 \%$, similar to rates of primary production, but exhibited little variation with depth, unlike rates of primary production, which decreased with increasing depth.

Rates of bacterial production ranged between 0.15 and $1.17 \mathrm{mg} \mathrm{C} \mathrm{m}^{-3} \mathrm{~d}^{-1}$ (mean of $0.44 \pm 0.34 \mathrm{mg} \mathrm{C} \mathrm{m}^{-3}$ $\mathrm{d}^{-1}$ ) (Fig. 5), and were on average 2.4 times higher than at non-bloom stations. Similar to non-bloom stations, bacterial production at bloom stations, accounted for between 0.1 and $13 \%$ of total carbon fixed by phytoplankton. Bacterial numbers ranged between 7.4 and $10.8 \times 10^{8}$ cells $1^{-1}$ (Fig. 5) and were 1.5 to 2.9 times higher than at non-bloom stations, and showed little variation with depth. 
The total biomass of plankton at Stns $7 \mathrm{a}$ and $7 \mathrm{~b}$ was 10 to 100 fold higher than at non-bloom stations (Fig. 6), and was dominated by diatoms, particularly Chaetoceros debelis, Rhizosolenia fragilissima and $R$. stolterfothii. The relative contribution of bacterial carbon to phytoplankton carbon decreased at bloom stations, relative to non-bloom stations to 7.1 and $7.9 \%$ for Stns $7 \mathrm{a}$ and $7 \mathrm{~b}$, respectively.

\section{Patterns in environmental variables}

Initial regression analysis of the data from all stations suggests that size-fractionated Cd uptake is positively related to size-fractionated rates of primary production and bacterial numbers, and negatively related to both concentration of nitrate and silicate (Table 2). In addition, for all stations (at the 33\% light level, the only depth with corresponding plankton identification), a statistically significant relationship was also found between $\mathrm{Cd}$ uptake in the $>5 \mu \mathrm{m}$ fraction and diatom biomass ( $\mathrm{r}=0.989, \mathrm{n}=5 \mathrm{p}<0.01)$.

Principal component analysis (PCA, Fig. 7) of the data shows that the coastal non-bloom Stns 1 and 4 cluster very close to each other, as do the bloom Stns $7 \mathrm{a}$ and $7 \mathrm{~b}$, irrespective of depth. However, the coastal non-bloom (Stns 1 and 4) and bloom (Stns 7a and 7b) stations, and the non-bloom offshelf station (Stn 6) tend to form distinct clusters, which suggests that they are described by different environmental datasets. Most of the environmental variability is captured in a 2D PCA approximation $(77 \%$, with $54.3 \%$ on the first PC axis and $22.7 \%$ on the second). The PCA plot (Fig. 7) has been overlaid with symbols proportional in size to $\mathrm{Cd}$ uptake in the $>5 \mu \mathrm{m}$ fraction. This clearly shows the high $\mathrm{Cd}$ uptake in the $>5 \mu \mathrm{m}$ fraction at bloom Stns $7 \mathrm{a}$ and $7 \mathrm{~b}$ compared to the non-bloom stations. The MDS ordinations of plankton species abundance (data not shown) at the $33 \%$ light equivalent water depth show similar patterns to the PCA environmental data (Fig. 7), and indicate that plankton species abundance

Table 2. Pearson correlation coefficients (r) for size-fractionated $\mathrm{Cd}$ uptake in the euphotic zone. Boldface $=\mathrm{p}<0.001$

\begin{tabular}{|lcr|}
\hline \multirow{2}{*}{ Parameter } & \multicolumn{2}{c|}{ Cd uptake } \\
\cline { 2 - 3 } & $0.2-5.0 \mu \mathrm{m}$ & $>5.0 \mu \mathrm{m}$ \\
& $(\mathrm{n}=39)$ & $(\mathrm{n}=39)$ \\
\hline Primary production & $\mathbf{0 . 6 4 6}$ & $\mathbf{0 . 8 4 7}$ \\
[Chlorophyll a] & -0.42 & $\mathbf{0 . 5 8 2}$ \\
Bacterial production & 0.251 & 0.220 \\
Bacterial numbers & $\mathbf{0 . 7 5 0}$ & $\mathbf{0 . 7 9 1}$ \\
[Nitrate] & $\mathbf{- 0 . 6 1 2}$ & $\mathbf{- 0 . 6 6 9}$ \\
[Silicate] & $\mathbf{- 0 . 6 0 7}$ & $\mathbf{- 0 . 6 5 2}$ \\
\hline
\end{tabular}

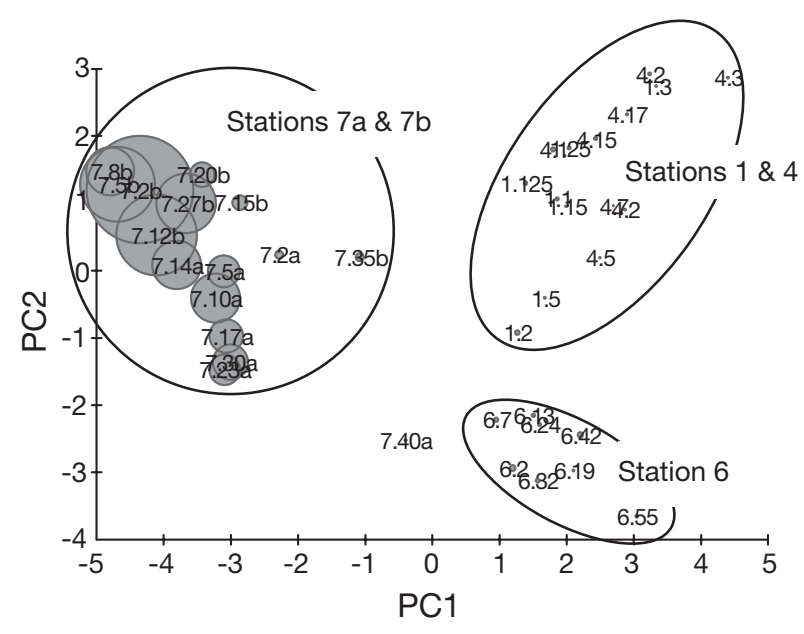

Fig. 7. Principal component analysis (PCA) of log-transformed environmental variables (Cd uptake, primary production, chlorophyll a concentration, bacterial production and bacterial numbers) for all stations. Coastal non-bloom Stns 1 and 4, coastal bloom Stns $7 \mathrm{a}$ and $7 \mathrm{~b}$ and offshelf non-bloom Stn 6 form spatially distinct clusters, as indicated by ellipses. Most of the variability $(77 \%)$ is captured in this $2 \mathrm{D}$ approximation with $54.3 \%$ on first PC axis and $22.7 \%$ on second PC axis

at the bloom stations was distinctly separated, and thus very different to, that at the non-bloom stations.

A RELATE significance test was applied to the plankton species abundance and environmental data (at $33 \%$ light equivalent depth) to test whether there was a significant relationship between the 2 data sets. Over 999 permutations gave a $\rho$ statistic of 0.867 at a significance level of 0.023 , confirming that the distribution of plankton species abundance between the stations was significantly related to observed changes in environmental variables between stations (particularly Cd uptake in $>5 \mu \mathrm{m}$ fraction, primary production and bacterial numbers). SIMPER analysis of plankton species abundance allowed the examination of the species which contribute to the differences (dissimilarity) between stations. For this data analysis, stations were again divided into non-bloom and bloom stations (Table 1). SIMPER analysis suggested that the average similarity in terms of plankton species abundance between non-bloom stations was $43.8 \%$, which was mainly due to the similarity in ciliate abundance (42.6\% of the total cumulative similarity) between Stns 1,4 and 6 . For the bloom stations, the average similarity was $66.6 \%$, with diatoms comprising $83.9 \%$ of the total cumulative similarity. The average difference (dissimilarity) in plankton species abundance between the non-bloom and bloom stations was $83.6 \%$. Of this, 5 diatom species (Rhizosolenia fragilissima $=31.5 \%$, Chaetoceros debelis $=16.1 \%$, Pseudo-nitzschia delicatissima $=9.9 \%, R$. stolterfothii $=6.5 \%, C$. laciniosus $=5.3 \%$ ) accounted for over two-thirds of the differ- 
ence between non-bloom and bloom stations, and 28 different plankton species overall accounted for over $90 \%$ of the distinctiveness of the bloom stations (85.8\% due to 21 diatom species).

\section{Cd uptake processes}

These results and statistical analysis of the nonbloom and bloom data suggest that uptake of Cd is significantly related to rates of primary production (particularly when the plankton is dominated by diatom species) and to bacterial numbers. Phytoplankton abundance analysis suggests that dominant diatoms such as Rhizosolenia, Chaetoceros and Pseudonitzschia species could be largely responsible for the higher amount of $\mathrm{Cd}$ uptake observed in the $>5 \mu \mathrm{m}$ fraction at the Lagrangian station compared to nonbloom stations. During the phytoplankton bloom, Cd uptake was more regulated by rates of primary production than by bacterial production, as evidenced by the lack of any statistically significant relationships between Cd uptake and bacterial production (Table 2).

Whilst Cd uptake can be correlated with (and thus related to) such biotic variables, it is difficult to determine absolutely whether $\mathrm{Cd}$ is actively or passively assimilated, i.e. whether $\mathrm{Cd}$ is an essential requirement for phytoplankton and therefore able to limit productivity (Hunter \& Boyd 1999), or is passively adsorped onto biotic particle surfaces. Luoma et al. (1998) observed a $50 \%$ reduction in the concentration of dissolved Cd in the water during a phytoplankton bloom in San Francisco Bay, which they attributed to phytoplankton uptake through passive adsorption onto the new surface area provided by the bloom, and active metal incorporation into the phytoplankton cells. A large proportion of $\mathrm{Cd}$, compared to many other metals, is taken up into labile intracellular fractions of the phytoplankton cytosol (Collier \& Edmonds 1984, Reinfelder \& Fisher 1991). These authors therefore concluded that such intracellular uptake would add a new sink for Cd during phytoplankton blooms, thus enhancing the depletion observed from solution and supporting the argument that active uptake by phytoplankton must be occurring.

Relatively recent discoveries of a specific $\mathrm{Cd}$ containing carbonic anhydrase (CA) in Thalassiosira weissflogii (Lane \& Morel 2000), and an extracellular Cd containing alkaline phosphatase in coccolithophores (see http://geoweb.princeton.edu/research/ biogeochem/cadmium.html) provide specific examples of essential functions that Cd can fulfil in plankton, which also suggest that active assimilation occurs. Carbonic anhydrases regulate levels of carbon dioxide within cells and are ubiquitous in bacteria (Lionetto et al. 2005) and marine phytoplankton. All previously characterised CAs incorporate an atom of $\mathrm{Zn}$ into the active site (Lane et al. 2005), so the extent to which phytoplankton species, other than T. weissflogii, use other trace metal containing CAs is largely unknown at present, although extremely likely given the low concentrations of $\mathrm{Zn}$ often found in the surface waters of the oceans (Lane et al. 2005). Given the recent demonstrated need for $\mathrm{Cd}$, its biochemical utilisation by diatoms and coccolithophores has been postulated to be the key to the ocean biogeochemistry of $\mathrm{Cd}$, and also perhaps to the ecology of these dominant phytoplankton taxa (see http://geoweb.princeton.edu/ research/biogeochem/cadmium.html). However, in the experiments reported in this study, it is unlikely that the phytoplankton were Zn limited as Ellwood \& Van den Berg (2000) reported total surface Zn concentrations in the order of $0.50 \mathrm{nM}$ for this region, with free $\mathrm{Zn}^{2+}$ concentrations of ca. 25 pM. Sunda \& Huntsmann (1992) reported that typical coastal diatom species (T. weissflogii and T. pseudonana) were limited at $\mathrm{Zn}^{2+}$ concentrations $<10 \mathrm{pM}$; it is therefore unlikely that the phytoplankton in the bloom observed here were limited by $\mathrm{Zn}$, and therefore the high Cd uptake observed coincident with higher rates of primary production was unlikely to be due to Zn limited Cd CA production. However, this does not necessarily preclude production of $\mathrm{Cd} \mathrm{CA}$ or other, as yet largely unidentified, active $\mathrm{Cd}$ uptake mechanisms.

Additional evidence for Cd uptake in the same area of the Celtic Sea comes from Cotté-Krief et al. (2002, references therein), who showed that $\mathrm{Cd}$ profiles perfectly mimic the nitrate and phosphate distributions over the whole water column, with a surface depletion down to $15 \mathrm{pM}$ and a rapid concentration increase in the seasonal thermocline, and below in the permanent thermocline. They further reported that average $\mathrm{Cd}$ concentrations decreased by $41 \%$ between winter and summer (cf. 36\% decrease for nitrate), which was attributed to seasonal stratification and biological uptake. Despite the apparent match between dissolved $\mathrm{Cd}$ and nutrient profiles, there is still the possibility that $\mathrm{Cd}$ is bound to the surface of the phytoplankton and subsequently released upon regeneration, i.e. passive uptake only (Collier \& Edmonds 1984). However, Cd removal rates between winter and summer similar to those reported by CottéKrief et al. (2002), were also found by Kremling \& Pohl (1989) in the surface waters of the NE Atlantic (56 $\pm 16 \%$ for $\mathrm{Cd})$. If typical surface dissolved Cd concentrations of $104 \pm 18$ pM in winter and depleted surface values of $65 \pm 43 \mathrm{pM}$ in summer are considered representative of the Celtic Sea (Cotté-Krief et al. 2002 and present study), and an average winter total Cd uptake rate of $0.13 \mathrm{pmol} \mathrm{l}^{-1} \mathrm{~d}^{-1}$ is taken for the 
winter months (January to March inclusive) and an average rate of $0.64 \mathrm{pmol}^{-1} \mathrm{~d}^{-1}$ for the spring/summer months (April to June inclusive), then this would represent a total $\mathrm{Cd}$ uptake of $\sim 70 \mathrm{pM}$ between the beginning of January and the end of June (cf. 39 pM inferred from concentration data). The $\mathrm{Cd}$ uptake rates reported in the present study are therefore consistent with the seasonal depletion of $\mathrm{Cd}$ reported in the literature, and can be attributed to uptake by phytoplankton bloom material. Subsequent replenishment by winter mixing of deeper thermocline waters with higher Cd content resets the surface concentrations to higher values.

Further evidence of Cd uptake by phytoplankton comes from Turner et al. (1992), who reported that plankton particulate samples had higher concentrations of $\mathrm{Cd}$ than lithogenic particulate matter, and that the $5 \mathrm{~d} K_{D}$ dissolved to particulate partition coefficient was 4 times higher for diatoms than for the prymnesiophyte Phaeocystis, suggesting enhanced association of $\mathrm{Cd}$ with diatom material. Results of the present work also showed plankton samples characterised by high ratios of $K_{D}\left({ }^{109} \mathrm{Cd}\right)$ compared to $K_{D}\left({ }^{65} \mathrm{Zn}\right)$, which was attributed to preferential assimilation of $\mathrm{Cd}$ relative to Zn in plankton macromolecules (see Price \& Morel 1990). Radiochemical tracer studies by Dixon (1998) using ${ }^{109} \mathrm{Cd}$ during spring and summer also showed higher $K_{D}$ values during summer coincident with high diatom biomass (up to $82 \mathrm{mg} \mathrm{C} \mathrm{m} \mathrm{m}^{-3} \mathrm{~d}^{-1}$ ), with a significant linear relationship found between $\mathrm{Cd}$ uptake and diatom biomass $(\mathrm{r}=0.92, \mathrm{n}=6 \mathrm{p}<0.05)$ in the Humber plume area of the western North Sea.

\section{$\mathrm{Cd}: \mathrm{C}$ ratios}

The calculated total Cd uptake rates were normalised to phytoplankton biomass, taken as the con-

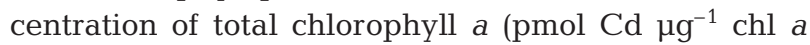
$\mathrm{d}^{-1}$ ), and plotted against normalised total primary pro-

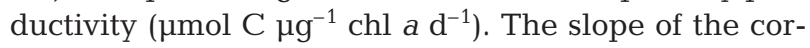
relation line thus yields the $\mathrm{Cd}$ content of the phytoplankton (pmol Cd $\mathrm{Cmol}^{-1} \mathrm{C}$, Fig. 8a), which gives a $\mathrm{Cd}$ :C ratio of $3.1 \mu \mathrm{mol} \mathrm{mol}{ }^{-1}$ for natural plankton samples from the Celtic Sea. This agrees well with previous culture studies, which have reported ratios between 0.1 and $5.0 \mu \mathrm{mol} \mathrm{mol}^{-1}$ for the coastal diatoms Thalassiosira weissflogii and T. pseudonana for concentrations of $\mathrm{Cd}^{2+}$ between 1 and 100 pM (Sunda \& Huntsman 1998, 2000). In a comprehensive analysis of 15 marine eukaryotic phytoplankton in culture, Ho et al. (2003) reported $\mathrm{Cd}: \mathrm{C}$ ratios of $0.77 \mu \mathrm{mol} \mathrm{mol}{ }^{-1}$ for T. weissflogii (calculated using a T. weissflogii C:P of 86 from Ho et al. 2003), but found that Cd quotas ranged over 2 orders of magnitude for the 15 phyto-
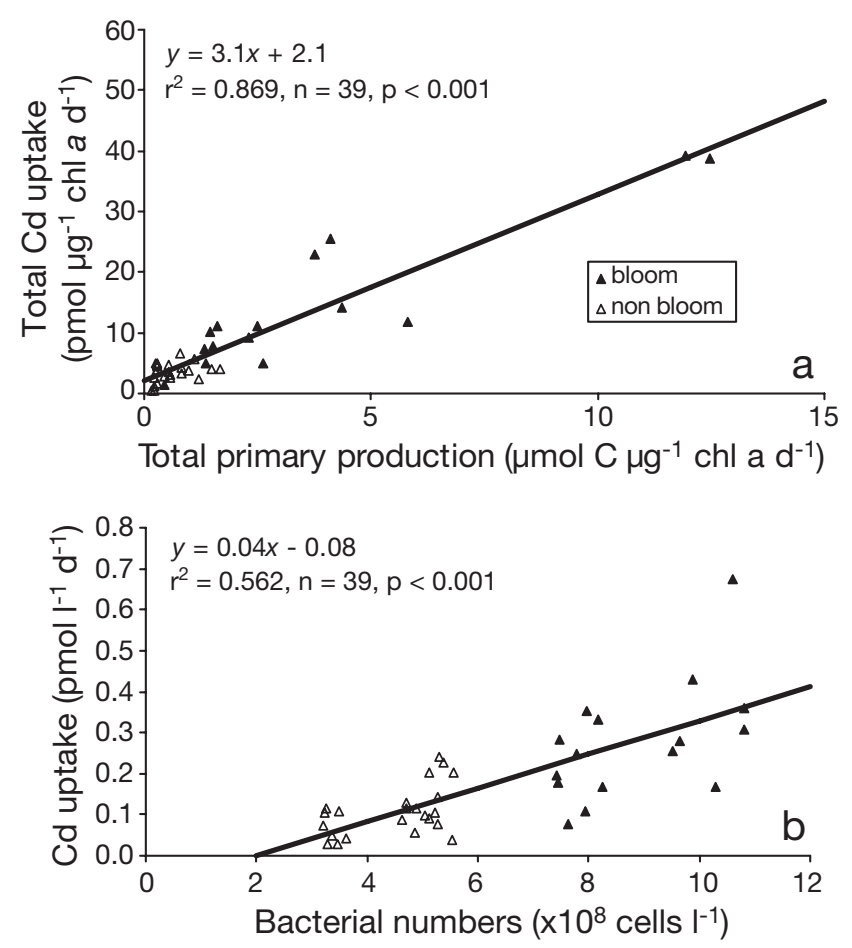

Fig. 8. Cd uptake at non-bloom and bloom stations. (a) Total uptake versus total primary production (both normalised to chlorophyll a); (b) uptake by 0.2 to $5.0 \mu \mathrm{m}$ fraction versus bacterial numbers

plankton species analysed (from estuarine, coastal and oceanic areas). Higher cellular $\mathrm{Cd}$ ratios have been reported for oceanic diatoms $\left(0.1\right.$ to $\left.10 \mu \mathrm{mol} \mathrm{mol}{ }^{-1}\right)$ and coccolithophores $\left(>100 \mu \mathrm{mol} \mathrm{mol}{ }^{-1}\right)$, which is thought to be a result of low ambient seawater concentrations of dissolved $\mathrm{Fe}$ and $\mathrm{Zn}$ inducing higher levels of $\mathrm{Cd}$ uptake by phytoplankton (Sunda \& Huntsman 2000). Initial Cd:C ratios reported by Cullen et al. (2003) for natural phytoplankton assemblages from the Southern Ocean were $\sim 19.5 \mu \mathrm{mol} \mathrm{mol}{ }^{-1}$, which decreased to 14.7 and $5.7 \mu \mathrm{mol} \mathrm{mol}{ }^{-1}$ after addition of $\mathrm{Zn}(+10 \mathrm{nM})$ and Fe (+2.5 nM), respectively. The initial high $\mathrm{Cd}$ :C ratios in Southern Ocean phytoplankton were thought to result from low temperatures, low $\mathrm{Fe}$, and low light conditions, all of which conspire to produce low growth conditions (Sunda \& Huntsman 1997) that favour elevated particulate Cd:P ratios (Cullen et al. 2003).

The relationship between normalised Cd uptake and primary production is not statistically significant for the non-bloom stations, which suggests that high cellular $\mathrm{Cd}$ concentrations are only observed during diatom spring bloom conditions. The positive $y$-intercept of $2.14{\mathrm{pmol} \mathrm{\mu g}^{-1} \mathrm{chl} \mathrm{a} \mathrm{d}}^{-1}$ (Fig. 8a) suggests passive surface adsorption of $\mathrm{Cd}$ by particulate organic material, e.g. dead or decaying phytoplankton cells. 
This is supported by data from the North Sea, which showed enhanced particulate $\mathrm{Cd}$ concentrations in the spring and summer compared to the autumn and winter, and was attributed to preferential adsorption by biogenic particulate matter (Tappin et al. 1995, Dixon 1998).

Similar analysis of the data set between Cd uptake and bacterial production (to attain $\mathrm{Cd}$ :bacterial C) was not calculated because of the non significant linear relationship between these 2 processes (Table 2). However, Cd uptake was significantly related to bacterial numbers (Fig. 8b), presumably due to surface adsorption of metal ions onto bacterial particles with high specific surface area. This does not mean that bacteria do not actively incorporate $\mathrm{Cd}$, but that uptake is not related to bacterial protein production, as measured by ${ }^{3} \mathrm{H}$ leucine incorporation.

\section{CONCLUSIONS}

We have shown surface adsorption of Cd onto bacterial surfaces and biogenic non-living particles, i.e. 'passive Cd uptake', which was significantly augmented during a spring diatom bloom relative to non bloom stations, with increases in $\mathrm{Cd}$ uptake rates in both size fractions suggesting increased sorption by bacteria and phytoplankton. Resulting particulate $\mathrm{Cd}$ :C ratios of $3.1 \mu \mathrm{mol} \mathrm{mol}{ }^{-1}$ are in good agreement with previously published literature values for cultured coastal diatoms and with field studies. What is not clear, is the reason for this enhanced Cd uptake, and whether an active or passive uptake mechanism is involved. During bloom conditions, $\mathrm{pCO}_{2}$ is expected to be lower, and thus a carbon concentrating mechanism (such as Cd CA) may be invoked, arguing for an active process. However, literature studies have only suggested Cd CA activity under limiting conditions of dissolved $\mathrm{Zn}$, which are thought to have been unlikely during this study. We need a better understanding of the function of $\mathrm{Cd}$ in phytoplankton and bacteria in order to establish whether the observed $\mathrm{Cd}$ uptake is an active or passive process, and whether this changes in response to prevailing biogeochemical conditions.

Acknowledgements. We acknowledge the captain, officers, crew and fellow scientists of the RRS 'Discovery' for their support during Cruise D261. We especially thank A. Rees and J. Stephens for the macronutrient analysis, primary production data analysis and help during the cruise. This work was funded by a grant from Natural Environment Research Council (NERC)-UK, as part of its Marine and Freshwater Microbial Biodiversity programme (GST/02/2832), and is a contribution to the NERC funded Plymouth Marine Laboratory core strategic research programme.

\section{LITERATURE CITED}

Boyle E, Sclater F, Edmond JM (1976) On the marine geochemistry of cadmium. Nature 63:42-44

Bruland KW, Franks RP, Martin JH, Knauer GA (1979) Sampling and analytical methods for the determination of copper, cadmium, zinc, and nickel at the nanogram per liter level in sea water. Anal Chim Acta 105:233-245

Clarke KR (1993) Non-parametric multivariate analysis of changes in community structure. Aust J Ecol 18:117-143

Clarke KR, Warwick RR (2001) Change in marine communities: an approach to statistical analysis and interpretation. PRIMER-E, Plymouth

Collier R, Edmonds J (1984) The trace element geochemistry of marine biogenic particles. Prog Oceanogr 13:113-199

Cotté-Krief MH, Thomas AJ, Martin JM (2002) Trace metal $(\mathrm{Cd}, \mathrm{Cu}, \mathrm{Ni}$ and $\mathrm{Pb})$ cycling in the upper water column near the shelf edge of the European continental margin (Celtic Sea). Mar Chem 79:1-26

Cullen JT, Sherrell RM (1999) Techniques for determination of trace metals in small samples of size fractionated particulate matter: phytoplankton metals off central California. Mar Chem 67:233-247

Cullen JT, Lane TW, Morel FMM, Sherrel RM (1999) Modulation of $\mathrm{Cd}$ uptake in phytoplankton by seawater $\mathrm{CO}_{2}$ concentration. Nature 402:165-166

Cullen JT, Chase Z, Coale KH, Fitzwater SE, Sherrel RM (2003) Effect of iron limitation on the cadmium to phosphorus ratio of natural phytoplankton assemblages from the Southern Ocean. Limnol Oceanogr 48:1079-1087

Dixon JL (1998) Trace metal particle water interactions in the western North Sea. PhD dissertation, University of Plymouth, Plymouth

Donald KM, Joint I, Rees AP, Woodward EMS, Savidge G (2001) Uptake of carbon, nitrogen and phosphorus by phytoplankton along the $20^{\circ} \mathrm{W}$ meridian in the NE Atlantic between $57.5^{\circ} \mathrm{N}$ and $37^{\circ} \mathrm{N}$. Deep-Sea Res II 48: 873-897

Ducklow HW, Kirchman DL, Anderson TR (2002) The magnitude of the spring bacterial production in the North Atlantic Ocean. Limnol Oceanogr 47:1684-1693

Ehrlich HL (1997) Microbes and metals. Appl Microbiol Biotechnol 48:67-692

Ellwood MJ, Van den Berg CMG (2000) Zinc speciation in the northeastern Atlantic ocean. Mar Chem 68:295-306

Flatau GN, Clement RL, Gauthier MJ (1988) Uptake of cadmium by marine bacteria. Prog Oceanogr 21:181-188

Ho TY, Quigg A, Finkel ZV, Milligan AJ, Wyman $\mathrm{K}$, Falkowski PG, Morel FMM (2003) The elemental composition of some marine phytoplankton. J Phycol 39: $1145-1159$

Holm-Hansen O, Lorenzen CJ, Holmes RW, Strickland JDH (1965) Fluorometric determinations of chlorophyll. J Cons Perm Int Explor Mer 30:3-15

Hoppe HG, Gocke K, Koppe R, Begler C (2002) Bacterial growth and primary production along a north-south transect of the Atlantic Ocean. Nature 416:168-171

Hu Z, Chandran K, Grasso D, Smets BF (2002) Effect of nickel and cadmium speciation on nitrification inhibition. Environ Sci Technol 36:3074-3078

Hunter KA, Boyd P (1999) Biogeochemistry of trace metals in the ocean. Mar Freshw Res 50:739-753

IOC (Intergovernmental Oceanographic Commission) (1994) Protocols for the Joint Global Ocean Flux Study (JGOFS) core measurements. Manual guide No. 29. IOC, Paris

Joint I, Pomroy A (1987) Activity of heterotrophic bacteria in the euphotic zone of the Celtic Sea. Mar Ecol Prog Ser 41: 
155-165

Joint I, Pomroy A (1993) Phytoplankton biomass and production in the southern North Sea. Mar Ecol Prog Ser 99: 169-182

Joint I, Owens NJP, Pomeroy A (1986) Seasonal production of photosynthetic picoplankton and nanoplankton in the Celtic Sea. Mar Ecol Prog Ser 28:251-258

Joint I, Wollast R, Chou L, Batten S and 23 others (2001) Pelagic production at the Celtic Sea shelf break. Deep-Sea Res II 48:3049-3081

Kremling K (1985) The distribution of cadmium, copper, nickel, manganese, and aluminium in surface waters of the open Atlantic and European shelf area. Deep-Sea Res 32:531-555

Kremling K, Pohl C (1989) Studies on the spatial and seasonal variability of dissolved $\mathrm{Cd}, \mathrm{Cu}$ and $\mathrm{Ni}$ in the north-east Atlantic surface waters. Mar Chem 27:43-60

Lane TW, Morel FMM (2000) A biological function for cadmium in marine diatoms. Proc Natl Acad Sci USA 97: 4626-4631

Lane TW, Saito MA, George GN, Pickering IJ, Prince RC, Morel FMM (2005) A cadmium enzyme from a marine diatom. Nature 435:42-43

Le Gall AC, Statham PJ, Morley NH, Hydes DJ, Hunt CH (1999) Processes influencing distributions and concentrations of $\mathrm{Cd}, \mathrm{Cu}, \mathrm{Mn}$ and $\mathrm{Ni}$ at the North West European shelf break. Mar Chem 68:97-115

Lionetto MG, Caricato R, Erroi E, Giordano ME, Schettino T (2005) Carbonic anhydrase-based environmental bioassay. Int J Environ Anal Chem 85:895-903

Luoma SN, van Geen A, Lee BG, Cloern JE (1998) Metal uptake by phytoplankton during a bloom in South San Francisco Bay: implications for metal cycling in estuaries. Limnol Oceanogr 43:1007-1016

Morel FMM, Price NM (2003) The biogeochemical cycles of trace metals in the oceans. Science 300:944-947

Pemberton K, Rees AP, Miller PI, Raine R, Joint I (2004) The influence of water body characteristics on phytoplankton diversity and production in the Celtic Sea. Cont Shelf Res 24:2011-2028

Price NM, Morel FMM (1990) Cadmium and cobalt substitution for zinc in a marine diatom. Nature 344:658-660

Rees AP, Joint I, Donald KM (1999) Early spring bloom phytoplankton-nutrient dynamics at the Celtic Sea shelf edge. Deep-Sea Res I 46:483-510

Reinfelder JR, Fisher NS (1991) The assimilation of elements ingested by marine copepods. Science 251:794-796

Editorial responsibility: Fereidoun Rassoulzadegan, Villefranche-sur-Mer, France
Simon M, Azam F (1989) Protein content and protein synthesis rates of planktonic marine bacteria. Mar Ecol Prog Ser 51:201-213

Smith DC, Azam F (1992) A simple, economical method for measuring bacterial protein synthesis rates in seawater using ${ }^{3} \mathrm{H}$-leucine. Mar Microb Food Webs 6:107-114

Statham PJ (1985) The determination of dissolved manganese and cadmium in sea water at low nmol $\mathrm{l}^{-1}$ concentrations by chelation and solvent extraction followed by electrothermal atomic absorption spectrometry. Anal Chim Acta 169:149-159

Sunda WG, Huntsman SA (1992) Feedback interactions between zinc and phytoplankton in seawater. Limnol Oceanogr 37:25-40

Sunda WG, Huntsman SA (1997) Interrelated influence of iron, light and cell size on marine phytoplankton growth. Nature 390:389-392

Sunda WG, Huntsman SA (1998) Control of Cd concentrations in a coastal diatom by free ionic $\mathrm{Cd}, \mathrm{Zn}$, and $\mathrm{Mn}$ in seawater. Environ Sci Technol 32:2961-2968

Sunda WG, Huntsman SA (2000) Effect of Zn, Mn, and Fe on $\mathrm{Cd}$ accumulation in phytoplankton: implications for oceanic Cd cycling. Limnol Oceangr 45:1501-1516

Tappin AD, Millward GE, Statham PJ, Burton JD, Morris AW (1995) Trace metals in the central and southern North Sea. Estuar Coast Shelf Sci 41:275-323

Turner A, Millward GE, Bale AJ, Morris AW (1992) The solidsolution partitioning of trace metals in the southern North Sea - in situ radiochemical experiments. Cont Shelf Res 12:1311-1329

Utermöhl H (1958) Zur Vervollkommnung der quantitativen Phytoplankton Methodik. Mitt Int Ver Theor Angew Limnol 9:1-38

Widdicombe $\mathrm{CE}$, Archer SD, Burkhill $\mathrm{PH}$, Widdicombe S (2002) Diversity and structure of the microplankton community during a coccolithophore bloom in the stratified northen North Sea. Deep-Sea Res II 49:2887-2903

Yee N, Fein J (2001) Cd adsorption onto bacterial surfaces: a universal adsorption edge. Geochim Cosmochim Acta 65: $2037-2042$

Zubkov MV, Sleigh MA, Burkill PH, Leakey RJG (2000) Picoplankton community structure on the Atlantic Meridional Transect: a comparison between seasons. Prog Oceanogr 45:369-386

Zubkov MV, Sleigh MA, Burkill PH (2001) Heterotrophic bacterial turnover along the $20^{\circ} \mathrm{W}$ meridian between $59^{\circ} \mathrm{N}$ and $37^{\circ} \mathrm{N}$ in July 1996. Deep-Sea Res II 48:987-1001

Submitted: January 8, 2006; Accepted: April 4, 2006

Proofs received from author(s): July 24, 2006 